\title{
シンポジウム クラゲ類の大量発生とそれらを巡る生態学・生化学・利用学
}

\section{II-3． 魚類との相互関係}

\author{
広 海 十 朗
}

\section{日本大学生物資源科学部}

II-3. Ecological relationship between jellyfishes and fishes

JURO HIROMI

College of Bioresource Sciences, Nihon University, Fujisawa, Kanagawa 252-8510, Japan

浮遊性のハイドロ水母, 管水母, 鉢水母などの刺胞動 物ならびにカブトクラゲ，ウリクラゲなどの有櫛動物が 世界的に増えている。1)これらクラゲ類の大量出現（発 生）は漁業や電力産業などに甚大な被害を及ぼす。2-4) しかし，クラゲ類の大量出現のもたらす問題はこれに止 まらない。すなわち, プランクトン生態系に打けるエネ ルギー流（図 1）が魚類の生産へと至るような通常の食 物連鎖（muscle food chain）が，将来，魚類にではな くクラゲ類の生産へ流れるもの（jelly food chain）にシ フトするのでは，と懸念される。

当然のことながら，このようなシフトは人類にとって 歓迎されない。したがって，今後このシフトの兆候を注 視すると同時にこのシフトの機構を解明したうえでこれ を予測できるようになることが望まれる。しかし，その 前に実に多くの問題が解明される必要がある。例えば， クラゲ類そのものの出現動態掞よびその機構解明, そし

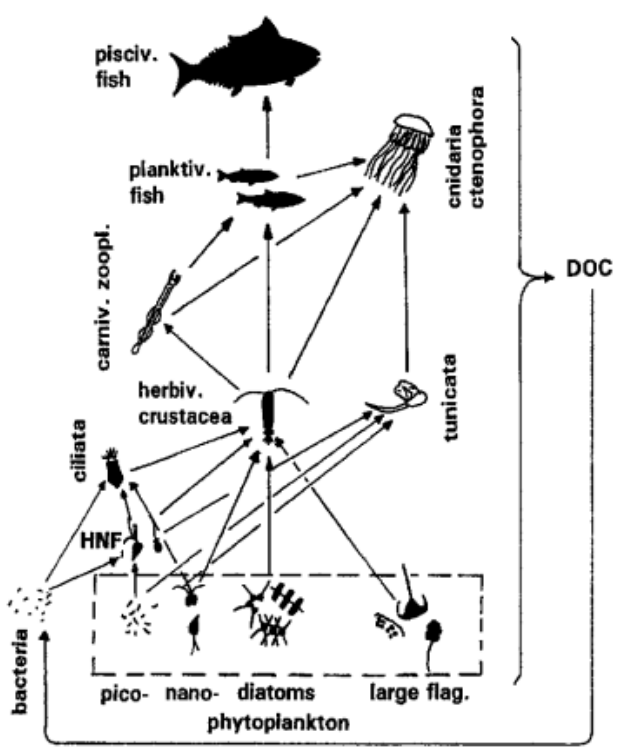

図 1 クラゲ類を取り入れた海洋の食物連鎖 (Sommer et al. 2002)
て，より定量的な把握の手法の確立などである。さら に, クラゲ類と魚類との関係に関わる生態学的知見もま た必要である。ここでは両者の生態学的関係を扱った研 究について概観し，知見の現状ならびに問題点を整理す る。

1. 魚類プランクトンに対するクラゲ類の捕食速度と捕 食圧

捕食速度はクラゲのサイズ，䬣生物のサイズとその密 度などに依存するが，クラゲのサイズに応じて捕食速度 が上昇する傾向がある。ニシン仔魚を与えられたミズク ラゲ Aurelia aurita の濾水速度でみると, 傘径 35-50 $\mathrm{mm}$ では平均 $204 l /$ 個体/日, $40-80 \mathrm{~mm}$ の個体では $526 \mathrm{l} /$ 個体/日であった。6) また, 仔魚個体群に対する補 食圧は 1.0-5.8\%/日と小さなものであった。しかしなが ら, 産卵期が特定かつ短い期間に限定されるような魚種 にとって大きな意味を持とう。ただし，クラゲ類の仔魚 捕食実験には方法論的にも困難な問題がある。例えば, 用いる実験容器の大きさによって得られる捕食速度は大 きく変動するので注意を要する。6) また，従来のクラゲ 捕食実験では魚類プランクトンだけを供することが多い が, 天然群集に近い条件, 少なくてもカイアシ類など他 の動物プランクトンの混在した条件下で測定することが 必要である。

\section{2. 魚類によるクラゲ類の捕食}

50 種類以上の魚類がクラゲ類を大なり小なり捕食し ていることが知られているが，そもそもクラゲは個体の 損失が早いので，より新鮮な胃内容物の試料を見ること によりクラゲ食性魚種はさらに増えるであろう。専らク ラゲを食べる例は知られていないが，クラゲ食のより強 い魚種としてマンボウを初めイボダイ科, マナガッオ 科, カサゴ科, サバ科が挙げられる。魚類のクラゲ消化 時間が不明であるため胃内容量から捕食速度を見積もる に至っていない。しかし, 魚類によるクラゲ捕食量は無 視できないであろう。

安倍7) は体長 $10 \mathrm{~cm}$ 前後のウマヅラハギにミズクラ 


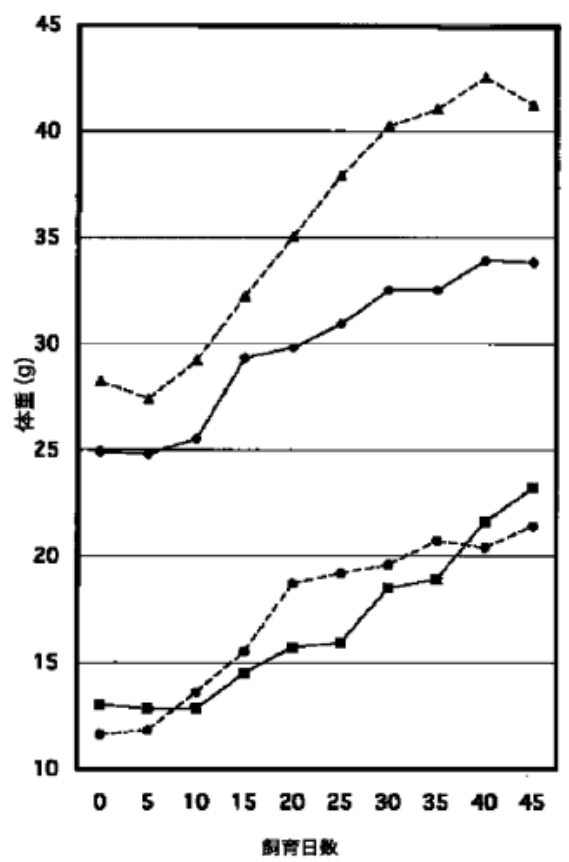

図 2 ウマヅラハギ供饘ミズクラゲ 2 個体（実線）なら びに人工飼料供餌個体（破線）の成長曲線

ゲを連日 1 個体ずつ与え，ウマヅラハギの成長を調べ た。対照として人工飼料を $2 \mathrm{~g} /$ 個体/日を与えた。得ら れた結果は図 2 に示すと抢りで, 体重, 体長の比成長 で見る限りミズクラゲ供䬣魚と対照個体にはほとんど差 が認められなかった。つまり，1日あたり抢抢よそ140 $\mathrm{g}$ のミズクラゲを食べたウマヅラ八ギの成長は $2 \mathrm{~g}$ の人 工飼料を食べた場合の成長に匹敵する。

\section{3. 競争}

イワシなどのプランクトン食魚類とクラゲ類はともに 動物プランクトンを主要な慨とするので，両者は競合関 係にあるものと見なされるが，実際に調べられた例は多 くない。Purcell \& Grover8) はニシン仔魚と 7 種のハイ ドロ水母を扱い，カイアシ類の幼生などの䭒生物に対す るハイドロ水母の補食圧が $0.2 \% /$ 日に過ぎないことか ら実際に競争はないものと考えた。1988 年以前の黒海 では動物プランクトンへの魚類（ヨーロッパアンチョ ビー）の捕食圧は高かったが，クシクラゲの Mnemiopsis leidyi が大量発生するようになった 1989 年以降魚 類の捕食圧は激減した。魚類がクシクラゲとの競合に負 けた結果であると考えられている。99

カタクチイワシの主要な餌料は小型カイアシ類である が，体長 40〜50 mm のカタクチイワシの最大飽食数は カイアシ類の Microsetella sp. で 300 500 個体と推定さ れている。10)消化時間が不明なので厳密な計算はできな いが，仮に 2 時間として，また，夜間はほとんど索餌 しないとして計算すればカタクチイワシは $1.8 \times 10^{3}$ か ら $3 \times 10^{3}$ 個体/日のカイアシ類を捕食することになる。
この值はミズクラゲの補食能よりも 1 〜オーダー低 く，これはすなわち，競合関係において 1 個体で比較 した場合ミズクラゲが魚類に勝るものとみなされる。11)

\section{4. 片利共生}

最も有名なものは管水母のカツオノエボシとエボシダ イとの“共生”であろう。他にも, アジ科, イボダイ科, マナガツオ科, タラ科の幼魚がクラゲの傘の下や触手付 近に群れでまつわりつくことが観察されている。これら の幼魚にとってクラゲは大型の捕食者（海鳥も含む）か らのシェルターの役割を持つのであろうが，魚は成長す るにつれクラゲの本体そのものをついばみ，あるいは餌 を横取りするようになり，両者の関係は一変する。これ らの魚種の刺胞毒に対する免疫能の獲得など, 生理・生 態学上興味深いものがあるが，その重要性を評価するた めには“共生”の時間的な長さ，その頻度などに関する 定量的な知見を得る必要がある。

最後に, 本研究は平成 14 年度 平成 16 年度科学研 究補助金（基盤研究 (C) (2)) のもとで行われたことを 記す。

\section{文献}

1) Mills CE. Jellyfish blooms: are populations increasing grobally in response to changing ocean conditions? Hydrobiologia 2001; 451: 55-68.

2）飯泉 仁. エチゼンクラゲの大量出現と漁業への影響. 日本プランクトン学会報 2005; 52: 32-35.

3） 木下淳司, 広海十朗. 相模湾におけるクラゲ類の出現と 漁業への影響. 日本プランクトン学会報 $2005 ; \mathbf{5 2}$ : 2027.

4）滝沢正登. 電力産業への影響一柏崎刈羽原子力発電所に おけるクラゲ対策の現状. 日本プランクトン学会報 2005; 52: 36-38.

5) Sommer U, Stibor H, Katechakis A, Sommer F, Hansen T. Pelagic food web configurations at different levels of nutrient richness and their implications for the ratio fish production: primary production. Hydrobiologia 2002; 484: $11-20$.

6) De Lafontaine $Y$, Legget WC. Effect of container size on estimates of mortality and predation rates in experiments with macrozooplankton and larval fish. Can. J. Fish. Aquat. Sci. 1987; 44: 1534-1543.

7）安倍基温. ミズクラゲと魚類の生態学的関係, 特に捕食被捕食関係について 平成 10 年度卒業論文, 日本大学 生物資源科学部, 神奈川. 1996.

8) Purcell JE, Grover JJ. Predation and food limitation as causes of mortality in larval herring at a spawning ground in British Columbia. Mar. Ecol. Prog. Ser. 1990; 59: 55-67.

9) Vinogradov ME, Shushukina EA, Bulgakova YuV. Consumption of zooplankton by the comb jelly Mnemiopsis leidyi and pelagic fishes in the Black Sea. Oceanology 1996; 35: 523-527.

10）林 小八, 工藤英郎, 小達和子, 小達 繁. 仙台湾の海 洋特性と生物生産について一カタクチイワシの生産を支 えている動物プランクトンに関する一考察一漁業 資源 研究会議報 1977; 47-64.

11）広海十朗, 粕谷智之, 石井晴人. クラゲ類のプランクト ン生態系に及ぼす影響 日本プランクトン学会報 2005 ; 52: $82-90$. 